\title{
Comparing two years of Saharan dust source activation obtained by regional modelling and satellite observations
}

\author{
I. Tegen ${ }^{1}$, K. Schepanski ${ }^{2}$, and B. Heinold ${ }^{1,2}$ \\ ${ }^{1}$ Leibniz Institute for Tropospheric Research, Leipzig, Germany \\ ${ }^{2}$ School of Earth and Environment, University of Leeds, Leeds, UK \\ Correspondence to: I. Tegen (itegen@tropos.de)
}

Received: 3 August 2012 - Published in Atmos. Chem. Phys. Discuss.: 22 October 2012

Revised: 6 February 2013 - Accepted: 8 February 2013 - Published: 1 March 2013

\begin{abstract}
A regional-scale dust model is used to simulate Saharan dust emissions and atmospheric distributions in the years 2007 and 2008. The model results are compared to dust source activation events compiled from infrared dust index imagery from the geostationary Meteosat Second Generation (MSG) satellite. The observed morning maximum in dust source activation frequencies indicates that the breakdown of nocturnal low level jets is an important mechanism for dust source activation in the Sahara. The comparison shows that the time of the day of the onset of dust emission is delayed in the model compared to the observations. Also, the simulated number of dust emission events associated with nocturnal low level jets in mountainous regions is underestimated in the model. The MSG dust index observations indicate a strong increase in dust source activation frequencies in the year 2008 compared to 2007 . The difference between the two years is less pronounced in the model. Observations of dust optical thickness, e.g. at stations of the sunphotometer network AERONET, do not show such increase, in agreement with the model results. This indicates that the number of observed dust activation events is only of limited use for estimating actual dust emission fluxes in the Sahara. The ability to reproduce interannual variability of Saharan dust with models remains an important challenge for understanding the controls of the atmospheric dust load.
\end{abstract}

\section{Introduction}

Soil dust aerosol is considered to be an important factor in the climate system (Solomon et al., 2007). Dust aerosol can impact upon climate directly by modifying the atmospheric ra- diation balance or indirectly by influencing cloud properties and biogeochemical cycles (e.g. Sokolik et al., 2001; DeMott et al., 2003; Jickells et al., 2005). An adequate description of dust source regions as well as the meteorological processes leading to dust emission are prerequisites for evaluating the influence of dust aerosol on the climate, as well as for understanding the response of dust distribution to changing climate conditions.

The Sahara Desert is the largest dust source worldwide. Saharan dust distributions are strongly variable at different timescales (e.g. Mahowald et al., 2006). Information on the sub-daily and seasonal occurrence of Saharan dust emission events is available from the geostationary Meteosat Second Generation (MSG) satellite infrared (IR) dust index since the year 2004 (Schepanski et al., 2007). The time of day when dust emissions are initiated can be an indicator for the meteorological processes causing dust emissions. The MSG observations suggest that approximately $60 \%$ of the Saharan dust events are initiated in the morning hours before 09:00 UTC (Schepanski et al., 2009), indicating the importance of turbulent downward mixing of momentum from nocturnal low level jets (LLJs) for activating dust sources (Washington and Todd, 2005). Seasonal changes in emissions and atmospheric transport of dust are characterized by variations in near-surface meteorology in connection with the seasonal displacement of the intertropical convergence zone and the African monsoon system (Schepanski et al., 2009; BouKaram et al., 2009). The causes of Saharan dust variability at multi-annual timescales are not well known. While observed variations in transported dust have been linked to drought conditions in the Sahel and North Atlantic Oscillation patterns (Prospero and Lamb, 2003; 
Chiapello et al., 2005), the study of variability of dust emissions is problematic due to the lack of available observations.

While the MSG dust source activation (DSA) dataset provides useful information about the occurrence of dust emissions events, models of dust emission and transport are useful to understand the relationships between the frequency of dust emission events, emission fluxes, and atmospheric dust loads. In an intercomparison of 14 different global dust models, Huneeus et al. (2011) show that the seasonal cycles and large-scale transport patterns of dust aerosol can be well reproduced by such models. However, large discrepancies in the results of the different models for results at individual locations indicate that dust processes may not be adequately resolved in such models. Regional-scale models that are commonly used for dust forecasts e.g. in the Mediterranean region (see http://sds-was.aemet.es/) are expected to better predict the meteorological features leading to dust emissions. Such processes include synoptic scale features like mesoscale convective systems in the southern Sahara, LLJs, and microscale processes related to dry convection, which have different seasonal and diurnal characteristics (Knippertz and Todd, 2012). Synoptic scale meteorological patterns leading to dust emissions like the Sharav cyclone in late winter/early spring in the northern part of the Sahara (Alpert and Ziv, 1989) are well reproduced by regional scale simulations. Problematic at the regional (as well as global) scale are simulations of dust emission processes related to wet convection (Knippertz et al., 2009; Reinfried et al., 2009) or dry convective events at microscale (e.g. dust devils, Koch and Renno, 2005). In this work we use the regional-scale Saharan dust model COSMO-MUSCAT (Heinold et al., 2007) to simulate the dust emission events and dust optical thicknesses for the years 2007 and 2008 using observed DSA from MSG dust index data for evaluation of the spatiotemporal distribution of modelled dust emission events.

\section{Methods}

\subsection{Model description}

The regional dust model system developed in the framework of Saharan Mineral Dust experiment SAMUM is described in detail by Heinold et al. (2007). It is based on the COnsortium for Small scale MOdellling (COSMO) meteorological model (Steppler et al., 2003), the operational weather model of the German Weather Service (Deutscher Wetterdienst, DWD), the online-coupled Chemistry-Transport-Model Multi-Scale Chemistry Aerosol Transport (MUSCAT) model (Wolke et al., 2004), and a dust emission scheme (Tegen et al., 2002). In MUSCAT, advection of chemical species and aerosol particles is computed by a third-order upstream scheme. Temporal integration is carried out by an implicit-explicit method. In the implicit-explicit scheme the horizontal advection is computed by an explicit second order Runge-Kutta method.
The chemistry and vertical transport processes are integrated with an implicit method. Dust emissions are computed by the model in non-vegetated areas. Emission fluxes depend on surface wind friction velocities, surface roughness, soil particle size distribution, and soil moisture (Heinold et al., 2007). Wind fields are assimilated from the COSMO model. Threshold friction velocities that must be reached to initiate dust emission depend on soil particle size distribution following Marticorena and Bergametti (1995). Within each model grid cell constant surface roughness lengths are assumed. Soil particle size distributions were derived from soil texture data (Zobler, 1986), assigning a composite of four particle size modes with mode diameters at $2 \mu \mathrm{m}, 15 \mu \mathrm{m}, 158 \mu \mathrm{m}$ and $720 \mu \mathrm{m}$ to each texture class (Tegen et al., 2002). Model grid cells where dust emissions are not observed in the MSG satellite observations during the years 2006 to 2009 (Schepanski et al., 2007) are excluded as dust source regions in the model. Thereby, model constraints due to uncertainties in soil data are fixed, while the actual placement and the predicted amount of dust emissions are controlled by COSMO surface winds. In the transport model MUSCAT dust is transported in five independent size classes with radius limits between $0.1 \mu \mathrm{m}$ and $24 \mu \mathrm{m}$ as dynamic tracer. Dust removal is computed considering dry and wet deposition processes. Dry deposition is computed following Seinfeld and Pandis (1998) and wet deposition (rain-out and wash-out) is parameterized according to Berge (1997). Wavelength-dependent dust optical thicknesses are computed from simulated dust concentrations, particle size distribution and extinction efficiencies as

$\tau=\sum_{i} \frac{3 Q_{\mathrm{ext}}\left(\lambda, r_{i}\right) M_{i}}{4 r_{i} \rho}$,

where $Q_{\text {ext }}$ is the dimensionless specific particle extinction efficiency (depending on wavelength $\lambda$; Lacis and Mishchenko, 1995), $\rho$ is the particle density, and $M_{i}$ is the aerosol mass load of size fraction $i$ characterized by the effective radius $r_{i}$.

The computation of radiative transfer of short- and longwave radiation in COSMO takes into account effects of scattering, absorption, and emission by aerosols, cloud droplets, and gases. It additionally considers the size-resolved dust optical thickness computed in the dust transport model. Thus the computation of radiation fluxes accounts for the spatially and temporally varying atmospheric dust load (Helmert et al., 2007).

A horizontal grid resolution of $28 \mathrm{~km}$ is used for the area between $0.2^{\circ} \mathrm{N}, 32.3^{\circ} \mathrm{W}$ and $41.1^{\circ} \mathrm{N}, 32.9^{\circ} \mathrm{E}$, including relevant Saharan dust sources, parts of Europe and the eastern tropical Atlantic. This domain ensures that synoptic and regional scale weather systems and local dust emissions are reproduced. The model is operated with 40 vertical layers of a pressure-based, terrain-following vertical coordinate; the lowest layer extends $68 \mathrm{~m}$. Simulations were performed for the full two years 2007 and 2008. COSMO simulations of the 
regional meteorology were initialized and the lateral boundary conditions are updated 6-hourly with analysis fields from the global model GME (Global Modell of the DWD). The simulations were re-initialized every $48 \mathrm{~h}$ to keep the meteorology of the regional model close to the analysis fields. After a spin-up of $24 \mathrm{~h}$ the COSMO model is coupled with MUSCAT to compute dust emission and transport, using modelled dust concentration from the previous cycle as initialization. The model has been extensively tested with observations from the SAMUM field study and available station and remote sensing data (Heinold et al., 2009, 2011).

\subsection{Meteosat second generation infrared dust index}

Brightness temperature differences converted from radiances of infrared wavelength channels measured by the SEVIRI (Spinning Enhanced Visible and InfraRed Imager) instrument on board the geostationary MSG satellite were used for Saharan dust detection at day- and nighttime. The qualitative index indicating the presence of mineral dust is computed from brightness temperatures of three different IR channels $(8.7 \mu \mathrm{m}, 10.8 \mu \mathrm{m}$, and $12.0 \mu \mathrm{m})$. The spatiotemporal resolution of the dust signal is determined by the sampling rate of $15 \mathrm{~min}$ and the spatial resolution of $3 \mathrm{~km}$ at nadir. No dust emission can be detected if thick clouds cover dust sources or the column water vapour is too high (Brindley et al., 2012). This signal was used to localize dust source activation events by visually tracing dust plume patterns back to their origin by inspecting consecutive images during dust events. Dust emitting areas were marked as DSA event on a $1^{\circ} \times 1^{\circ}$ gridded map for the Saharan region between $5^{\circ} \mathrm{N} 20^{\circ} \mathrm{W}$ and $40^{\circ} \mathrm{N} 40^{\circ} \mathrm{E}$. The monthly DSA frequencies (DSAF) were calculated for each grid cell in this region (Schepanski et al., 2007). High DSAF were identified in the Bodélé depression in Chad, but also near mountain foothill areas where fine sediment is available from fluvial sources, and high surface wind speeds frequently initiate dust emission events. The observed seasonal and diurnal patterns of dust emission help to understand the meteorological processes controlling the spatiotemporal patterns of dust emission in the different regions of the Saharan desert (Schepanski et al., 2009). A good agreement of the spatiotemporal variability of dust sources derived from the MSG dust index data and ground-based dust observations at meteorological stations in the Sahara has been found for a case study in spring/summer 2006 (Laurent et al., 2010). The dust source regions inferred from the backtracking of dust plumes differ from satellite-inferred dust source regions that are based on a high frequency of high daily dust aerosol loads, e.g. from the Ozone Monitoring Instrument Aerosol Index (OMI AI) or aerosol optical thickness derived from the Moderate Resolution Imaging Spectroradiometer (MODIS) (both flying on the NASA A-Train constellation). The differences were attributed to the temporal resolution of the different satellite retrievals (Schepanski et al., 2012).

\section{Results}

\subsection{Dust source activation frequencies}

Dust emissions in the Sahara desert are computed for the 2-yr model period. Simulated total annual dust emissions reach values of approximately $1900 \mathrm{Mt} \mathrm{yr}^{-1}$ for 2007 and $2300 \mathrm{Mt} \mathrm{yr}^{-1}$ for 2008 (Table 1). That the simulated emissions are higher compared to earlier publications (e.g. Laurent et al., 2008) can be due to the considered particle radius up to $24 \mu \mathrm{m}$, while in most publications only particles with radii less than $10 \mu \mathrm{m}$ are considered.

For direct comparison with the MSG data, the model results were re-binned to a resolution of $1^{\circ} \times 1^{\circ}$. To facilitate comparisons with the observed DSA from the MSG observations, the occurrence of dust emissions were counted when the emission flux in a model grid cell exceeded $6 \times$ $10^{-5} \mathrm{~kg} \mathrm{~m}^{-2}$ in a 3-h time interval. Only higher dust emission fluxes were counted as dust events to account for the fact that very minor dust events would not be detectable in the MSG data. The emission flux limit was chosen such that the 2-yr sum of counts of Saharan dust emission events for all Sahara gridboxes from both model and observations agreed with each other. It should be noted that the minor dust emission fluxes that were lower than the threshold to be counted as DSA in the model still contributed $18 \%$ in 2007 and $14 \%$ in 2008 to the total Saharan dust emission fluxes. To account for the fact that dust emissions cannot be detected from the satellite data when cloud cover is present, model DSA events were not counted when the model-simulated cloud cover in the grid cell during the respective day was higher than $50 \%$. The two-year sum of daily modelled dust emission counts for the Sahara were 25582 compared to 26249 counts for the MSG DSA (Table 1).

Results for the monthly sums of DSA for the Saharan domain including information on the time-of-day of the beginning of dust emissions are shown in Fig. 1. The modelled monthly total numbers of Saharan dust emission events show a pronounced seasonal cycle with a clear spring maximum, while the seasonality is less pronounced in the observations. The number of DSA in the MSG dataset increases by more than $100 \%$ in 2008 compared to 2007 (see also Table 1). The model results show also an increase in the number of DSA in 2008 , but only by $27 \%$. The higher number of DSA observed in 2008 is mainly due to increased emissions in the morning hours between 06:00 and 12:00 UTC (Fig. 1). The higher dust source activation at morning hours in 2008 points towards an increase in the occurrence of nocturnal LLJs that were identified to be major contributor to dust emission events in the Sahara (Washington and Todd, 2005; Schepanski et al., 2009). LLJs develop as consequence of the nocturnal stabilization of the boundary layer; their momentum is mixed to the surface by turbulence setting in after sunrise when the surface heats up. In average $65 \%$ of the simulated dust emission events (counted as events are simulated 
Table 1. Sahara dust results from the regional model COSMOMUSCAT for the years 2007 and 2008. DSA: Dust source activation. Over- and underpredictions refer to the percentage of grid cells between $15^{\circ} \mathrm{W}, 10^{\circ} \mathrm{N}$ and $32^{\circ} \mathrm{E}, 40^{\circ} \mathrm{N}$ that are activated compared to MSG IR dust index.

\begin{tabular}{lrr}
\hline Date & 2007 & 2008 \\
\hline Model annual dust emission (Mt) & 1870 & 2330 \\
Emission count (Model) & 11140 & 14442 \\
Emission events with LLJ & $40 \%$ & $39 \%$ \\
Emission count (MSG) & 7139 & 19110 \\
Percent grid cells overpredicting DSA & $29 \%$ & $23 \%$ \\
Overpredictions with LLJ & $12 \%$ & $9 \%$ \\
Overpredictions without LLJ & $17 \%$ & $14 \%$ \\
Percent grid cells underpredicting DSA & $10 \%$ & $16 \%$ \\
Underpredictions with added LLJs & $1 \%$ & $3 \%$ \\
\hline
\end{tabular}

dust fluxes in a model grid cell exceeding $6 \times 10^{-5} \mathrm{~kg} \mathrm{~m}^{-2}$ in a 3-h time interval) occur before noontime, which indicates that the breakdown of the nocturnal LLJ is also an important dust mobilization mechanism in the model.

The less pronounced diurnal cycle of DSA activation in the model compared to the observations is likely to be related to shortcomings in the turbulence parameterization and the lower boundary conditions such as model topography and surface roughness (Todd et al., 2008; Heinold et al., 2011). The results suggest that the downward mixing of momentum during the morning degradation of LLJs is delayed in the model. Thus, dust emission events related to the LLJ breakdown can occur later in the day compared to the observations. The boundary layer scheme may not cope with the nocturnal stable stratification resulting in too weak jets. In addition, the characteristic sharp morning wind peak is not always reproduced, as the turbulent mixing takes place too gradually. On the other hand, it also cannot be ruled out that the DSA observations are biased towards the morning hours, because dust emissions in the afternoon that occur in connection with wet convective events may be obscured by cloud cover and thus cannot be detected.

The spatial distribution of dust source activation frequencies are compared for the MSG observations and numbers of model dust emission events are shown in Fig. 2. Model results from the COSMO-MUSCAT and the MSG infrared dust source activation (DSA) events for the years 2007 and 2008 were averaged for months, in which similar meteorological conditions were dominant causes for dust emissions (Fig. 2, left and middle panels). In addition, the occurrence of LLJs in the model is shown (Fig. 2, right panels). The occurrence of nocturnal LLJs in the individual grid cells was computed from simulated wind speed differences above the nocturnal boundary layer. A nocturnal LLJ was assumed to have developed in a model grid cell if the wind speed difference between the layer directly above the boundary layer at 06:00 UTC and the layer located $200 \mathrm{hPa}$ above this layer
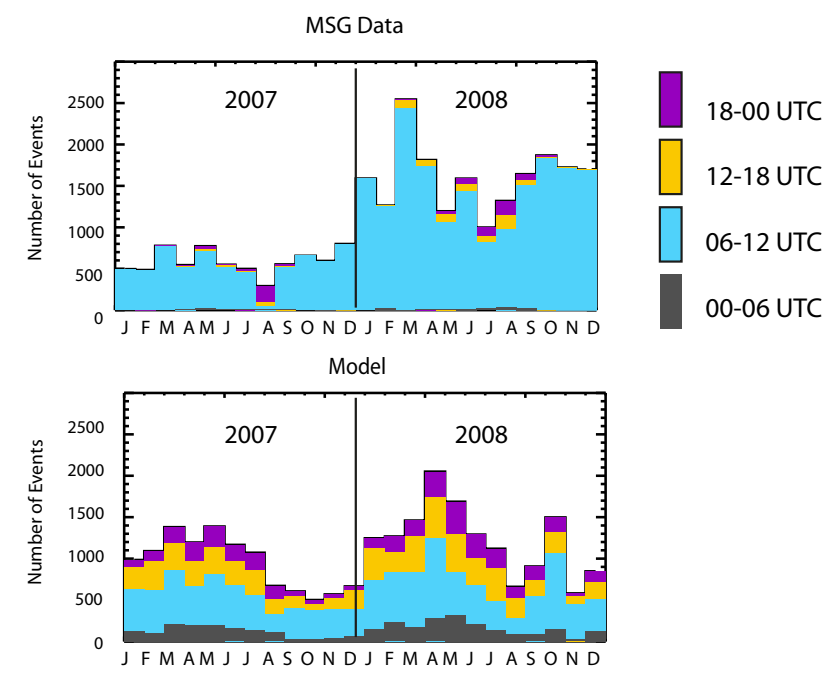

Fig. 1. Number of dust emission events in the Sahara for the years 2007 and 2008 derived from the MSG infrared dust index (top) and computed with the COSMO-MUSCAT model (bottom). The colors indicate the time of day when dust emission starts. Grey: 00:00-06:00 UTC, blue: 06:00-12:00 UTC, orange: 12:0018:00 UTC, purple: 18:00-00:00 UTC.

exceeds $5 \mathrm{~ms}^{-1}$ (this value was chosen in agreement with Schepanski et al., 2009). Forty percent (40\%) (2007) and $39 \%$ (2008) of the simulated DSA events in the model are associated with the occurrence of LLJs on the same day (Table 1). For the actual dust emission fluxes, $36 \%$ (2007) and $38 \%$ (2008) of the total annual Saharan dust emissions fluxes coincide with the occurrence of low level jets. In October to January (Fig. 2, lower panels) Saharan dust emissions are dominant in the Bodélé depression, here the occurrence of nocturnal LLJs are coincident with days of dust emissions. In the months from February to May the passages of Sharav cyclones are the cause of major dust emission events in northern Sahara (e.g. Alpert and Ziv, 1989, Horvath et al., 2006) (Fig. 2, top panels). In the summer months (June to September, Fig. 2, middle panels) mesoscale convective systems are major causes for dust emissions in the southern Sahara (Knippertz and Todd, 2012). Those events should occur less frequently than dust source activation by LLJs, but may be more important in terms of dust emission fluxes.

The figures illustrate the dominance of the Bodélé dust source in the winter months, the good agreement of the model and observations in this region, and the important role of LLJs for dust mobilization in the Bodélé, where nearly all dust emission events are occurring at the same days when LLJs develop. An overestimate of DSAs that are unrelated to the development of LLJs is evident in the northern Sahara. This may suggest that here the MSG observations underestimate DSA, as during these large scale events dust sources may become activated during the passage of Sharav cyclones below the passing dust cloud. These events would not be 


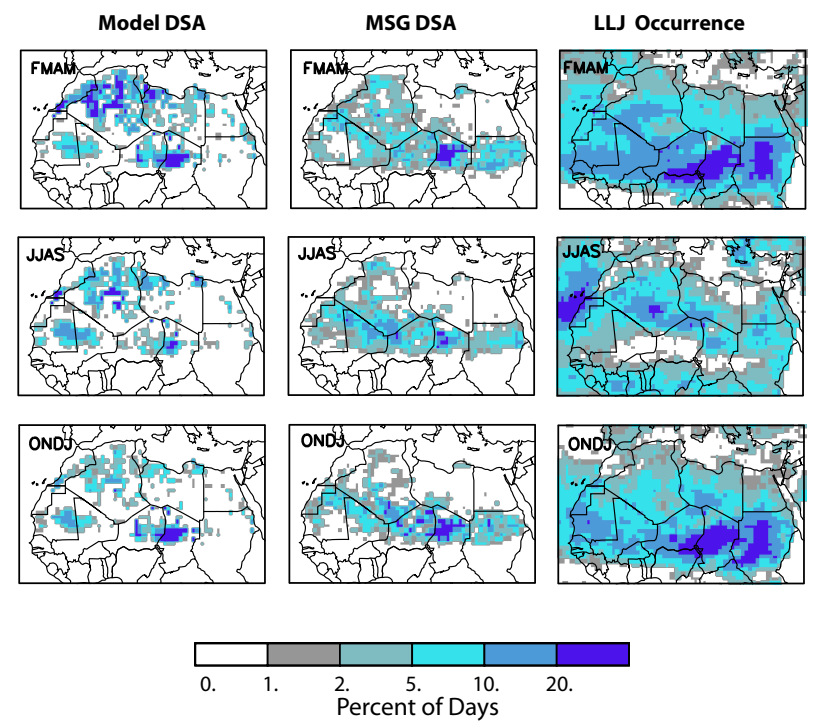

Fig. 2. Distribution of the percent of days when dust source activation occurs in the COSMO-MUSCAT model simulations (left panels) and derived from the MSG infrared dust index (middle panels). Right panels: occurrence of nocturnal low level jets in the COSMO model simulations. Results are average values for the years 2007 and 2008, averaged for the months February to May (top panels), June to September (middle panels) and October to January (bottom panels). The model results are binned into $1^{\circ} \times 1^{\circ}$ grid cells to facilitate comparison with the MSG data.

detected by the MSG imagery as new DSA (similar to events that occur below clouds during mesoscale convective events), leading to an underestimation of DSA in the observations. This underestimate may increase a bias towards the maximum number of dust emission events in the morning hours.

The MSG DSA data indicate a strongly increased dust activity in the year 2008 compared to 2007 . However, this increase is less evident in the model simulations (Figs. 1, $3)$. In both years the agreement between modelled and observed dust emission events is very good in the Bodélé region in Chad, which is the most active dust source in the Sahara desert. For the area between $15^{\circ} \mathrm{E}$ and $20^{\circ} \mathrm{E}, 15^{\circ} \mathrm{N}$ and $19^{\circ} \mathrm{N}$ the sum of emission events based on $1^{\circ} \times 1^{\circ}$ resolution for both years are 4095 for the model simulation compared to 4476 observed DSA events. While the overprediction of DSA in the annual averages occurs mostly in northern Saharan grid cells in both years, missed emissions are most evident for the annual average in the Sudan and the mountainous region along the border between Algeria, Mali and Niger (Fig. 3). In these regions dust emissions that are observed in the MSG record may be partly caused by high wind speeds that occur with the degradation of nocturnal LLJs when turbulent mixing sets in during the morning hours. As mentioned above, in the Bodélé dust hot spot almost all modelled dust emission events occur on days when a LLJ developed. In addition to the total number of Saharan dust emissions in the
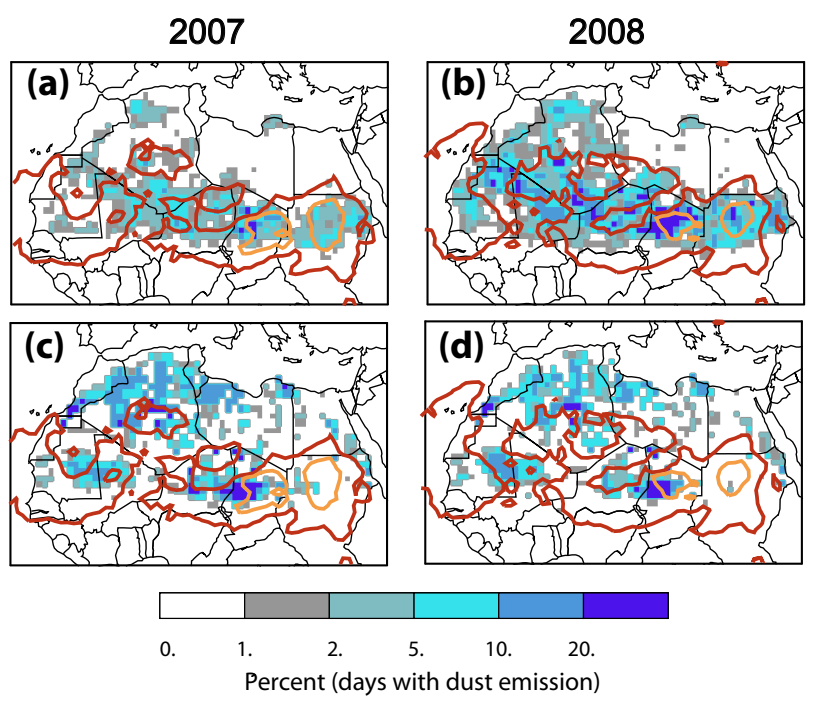

Fig. 3. Percent of days per month with dust emission derived from the MSG SEVIRI IR dust index $(\mathbf{a}, \mathbf{b})$ and simulated with the COSMO-MUSCAT model (c, d); for year 2007 (left) and 2008 (right). The red and orange contours indicate areas where the occurrence of low level jets in the model is higher than 15 and 30 percent of the days per year, respectively.

model compared to the MSG record the number of grid cells is given (summed over one year for the area between $15^{\circ} \mathrm{W}$ and $32^{\circ} \mathrm{E}, 10^{\circ} \mathrm{N}$ and $40^{\circ} \mathrm{N}$ ), for which the modelled monthly dust emission frequencies either exceed ("overpredictions" in Table 1) or are below the observed frequencies ("underpredictions" in Table 1). "Overpredictions" occur when dust emissions are predicted by the model but not observed, either due to too high modelled surface winds, incorrect parameterization of surface properties or undetected dust emission events in the satellite data. In $29 \%$ and $23 \%$ of the grid cells modelled DSA are overpredicted compared to the observations in 2007 and 2008, respectively. An overprediction can be caused by insufficient decoupling of the nocturnal boundary layer and too high surface winds at night and early morning hours in the model. As an overprediction of morning wind peaks due to the LLJ breakdown is unlikely (e.g. Todd et al., 2008; Heinold et al., 2011), the misrepresentation of other peak wind generating processes acting at the same time or a wrong placement of the LLJ are more likely reasons. Unrelated to the occurrence of LLJs, dust emissions that are caused by wet convective events, i.e. meso-scale convective systems in the southern Sahara and Sahel in summer and density currents in mountainous areas, may be misrepresented in the model (e.g. Reinfried et al., 2009; Marsham et al., 2011). On the other hand, potential deficits in the model capability to reproduce moist convection may be also obscured in favor of the model by the restriction of the MSG satellite product to cloud-free conditions. Under high humidity conditions the MSG dust signal is also obscured, which limits the 
possibility for dust detection in the Sahel. The percentage of grid cells where modelled dust emission events are underestimated compared to the observations is higher in 2008 (16\%) compared to 2007 (10\%) (Table 1). LLJs can develop but do not always lead to dust emissions in the model (Figs. 2 and 3). Nevertheless, increased LLJ occurrence in the summer months of the year 2008 compared to 2007 (Fig. 3) that corroborates the higher MSG DSA observations in 2008 points towards the importance of this phenomenon for dust mobilization even in the summer season. The reason for the lack of modelled dust mobilization following the development of nocturnal LLJs in mountainous regions may be due to too weakly developed LLJs or insufficient turbulent mixing of momentum towards the surface during the breakdown of the LLJs in the morning hours in the COSMO model. Also, the assumption of too high roughness lengths in the dust emission model that suppresses dust emission may not be representative for fluvial dust sources that may in fact be highly productive dust sources. If the number of days with LLJ occurrences but without dust emissions are added to the dust emission events in those model grid cells where dust emissions are underpredicted (i.e. implicitly assuming that all LLJ occurrences are followed by dust emission events), a close agreement is achieved between the model and observations with only $3 \%$ or less of the model grid cells remaining to underpredict dust emission events (Table 1). In that case, however, the total number of dust emissions would increase in the model, requiring an increase in the threshold for dust emission fluxes to be counted as DSA, in order to obtain an agreement between total numbers of DSA in the model and observations.

\subsection{Dust optical thickness}

While the spatiotemporal distribution of dust source activation events provides necessary information for relating dust particle properties to soil properties in the source regions and estimate the effects of changing climate conditions on dust emissions, the actual effects of atmospheric dust aerosol on the radiation balance, precipitation distribution and fertilization of ecosystems depends on the atmospheric dust loads, that is not necessarily related to dust source activation frequencies in particular regions. In the annual average, the modelled dust aerosol optical thickness (AOT) reaches values up to 0.3 that occur over the central and western parts of the Sahara, with highest values in the southern Sahara and the Bodélé region in Chad (Fig. 4a, b). As for the simulated DSAFs, AOTs are slightly higher in 2008 compared to 2007. Maximum values of annual average optical AOTs are 0.29 in 2007 compared to 0.32 in 2008. A qualitative comparison of model AOT averaged at 12:00 UTC with the annual averaged absorbing aerosol index (AI) measured by the Ozone Monitoring Instrument (OMI) (Torres et al., 2007) for the two years (Fig. 4c, d) shows similarities to the spatial distribution of the simulated dust aerosol. However, it should be noted
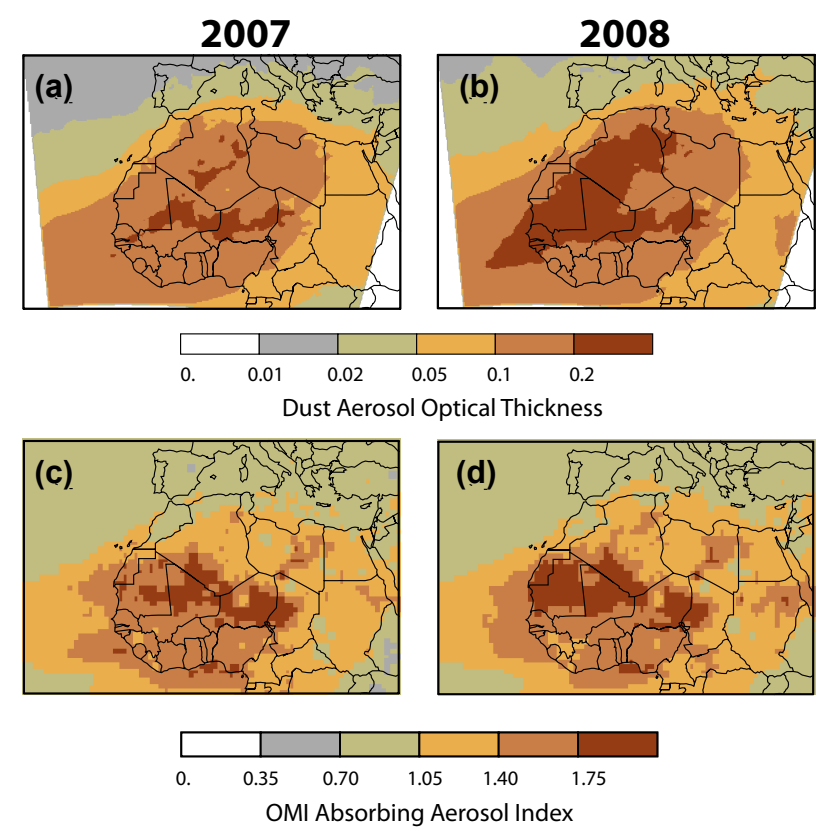

Fig. 4. Annual averaged dust optical thickness for the years 2007 (left panels) and 2008 (right panels) computed with COSMOMUSCAT (a, b); annual averaged absorbing aerosol index from the OMI satellite instrument $(\mathbf{c}, \mathbf{d})$.

that the OMI AI is only a qualitative indicator of the presence of dust aerosol, and is also sensitive to biomass burning smoke aerosol in the Sahel region, which is not considered in the model. Similar to the model results, the OMI AI shows slightly increased values in the year 2008 compared to 2007 , particularly in the northern part of the Sahara.

Quantitative evaluation of the model results at individual location is done by comparison with sunphotometer data from the Aerosol Robotic Network AERONET (Holben et al., 1998). We compare optical thickness observations at $440 \mathrm{~nm}$ with model results of dust optical thickness computed for $440 \mathrm{~nm}$ wavelength. Daily averaged AOT retrievals from the AERONET stations are compared to modelled daily averaged dust optical thickness results at the respective location. Here the daily model results are averaged for the time period between 09:00 and 15:00 UTC to account for the fact that the measurements can only be performed during daytime. Since anthropogenic aerosols are not simulated in this version of the regional model, only days are compared when the Ångstrom parameter is lower than 0.7, indicating a dominance of large dust particles on that day and location (Dubovik et al., 2002). Only few AERONET stations continuously operate in the dust-dominated regions in the Saharan desert. Here we compare measurements and model results for the years 2007 and 2008 for the stations Tamanrasset $\left(22.8^{\circ} \mathrm{N}, 5.5^{\circ} \mathrm{E}\right)$, Blida $\left(36.5^{\circ} \mathrm{N}, 2.9^{\circ} \mathrm{E}\right)$, Saada $\left(31.6^{\circ} \mathrm{N}, 8.2^{\circ} \mathrm{W}\right)$, Dakar $\left(14.4^{\circ} \mathrm{N}, 17.0^{\circ} \mathrm{W}\right)$, that are located in the vicinity of the Saharan desert, Banizoumbou $\left(13.5^{\circ} \mathrm{N}\right.$, 
Table 2. Comparison of model results of dust optical thickness with daily aerosol optical thickness measurements at 8 AERONET sunphotometer stations, averaged for the years 2007 and 2008. " $N$ " is the number of instances where daily AOT measurements are available for the two years, "Correlation" is the correlation coefficient between model and observations, "Bias" is the absolute mean difference between model dust optical thickness and measured AOT, "RSME" is the root mean square error.

\begin{tabular}{lrrrr}
\hline Station & $N$ & Correlation & Bias & RSME \\
\hline Saada $\left(31.6^{\circ} \mathrm{N}, 8.2^{\circ} \mathrm{W}\right)$ & 251 & 0.30 & -0.19 & 0.27 \\
Blida $\left(36.5^{\circ} \mathrm{N}, 2.9^{\circ} \mathrm{E}\right)$ & 134 & 0.41 & -0.19 & 0.30 \\
Tamanrasset $\left(22.8^{\circ} \mathrm{N}, 5.5^{\circ} \mathrm{E}\right)$ & 365 & 0.14 & -0.13 & 0.32 \\
Izana $\left(28.3^{\circ} \mathrm{N}, 16.5^{\circ} \mathrm{W}\right)$ & 169 & 0.37 & -0.02 & 0.12 \\
Capo Verde $\left(16.7^{\circ} \mathrm{N}, 22.9^{\circ} \mathrm{W}\right)$ & 528 & 0.46 & -0.17 & 0.28 \\
Dakar $\left(14.4^{\circ} \mathrm{N}, 17.0^{\circ} \mathrm{W}\right)$ & 568 & 0.36 & -0.21 & 0.34 \\
Agoufou $\left(15.3^{\circ} \mathrm{N}, 1.5^{\circ} \mathrm{W}\right)$ & 588 & 0.24 & -0.24 & 0.47 \\
Banizoumbou $\left(13.5^{\circ} \mathrm{N}, 3.7^{\circ} \mathrm{E}\right)$ & 631 & 0.43 & -0.34 & 0.53 \\
\hline
\end{tabular}

$\left.3.7^{\circ} \mathrm{E}\right)$ and Agoufou $\left(15.3^{\circ} \mathrm{N}, 1.5^{\circ} \mathrm{W}\right)$ in the Sahel, and the island locations Cape Verde $\left(16.7^{\circ} \mathrm{N}, 22.9^{\circ} \mathrm{W}\right)$ and Izana $\left(28.3^{\circ} \mathrm{N}, 16.5^{\circ} \mathrm{W}\right)$, that are located west of North Africa and frequently influenced by Saharan dust (Fig. 5). The locations of the Aeronet stations are also indicated in Fig. 6. For each station the total number of instances of daily station observations, as well as the average correlation coefficients, bias and root mean square error between model results and observations for the two years 2007 and 2008 are given in Table 2. Correlation coefficients are between 0.14 and 0.46 , the bias is negative at all stations, with values between -0.02 and -0.34 averaged for the two years. The negative bias can be explained by the fact that the measurements of aerosol optical thicknesses include all aerosol types (dust, anthropogenic aerosol, particles from biomass burning, marine aerosol), while the model only simulated dust aerosol optical thicknesses. In addition, the comparison with the sunphotometer observations may indicate cases where the model simulated dust emission fluxes are too low.

At these stations there is no clear difference in AOT magnitude between the two years. An increase in dust AOT in 2008 compared to 2007 is not observed or simulated for any station. The seasonal cycles and the large day-to-day variability in the Saharan dust load is however evident in the observations and model results. The magnitudes and timing of most individual AOT peaks indicating strong dust events are matched well by the model results. There is agreement in the seasonal variations at the stations Saada and Blida in the northern Sahara. The model underestimates the observed AOT during part of the year. This may be due to the influence of anthropogenic aerosol that is not included in the model. This influence is evident in particular at the station Blida, where the high Ångstrom coefficient indicate the presence of small non-dust particles. Notable discrepancies between the model results and the measurements occur at the Sahel stations Agoufou and Banizoumbou in Northern Hemisphere
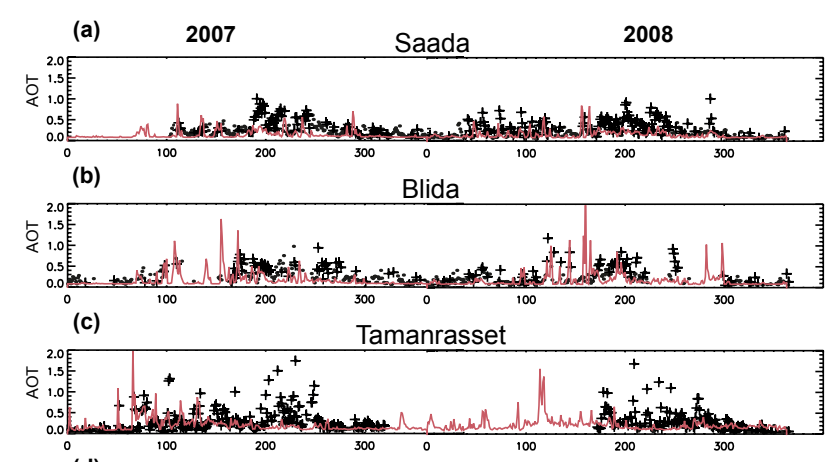

(d)
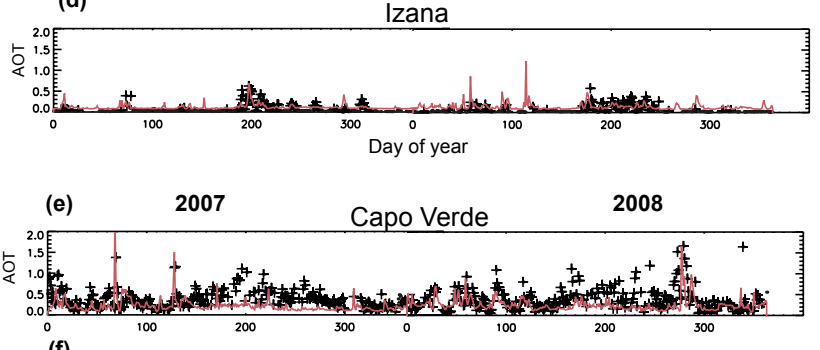

(f) Dakar

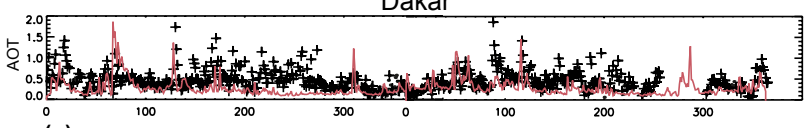

(g) Agoufou

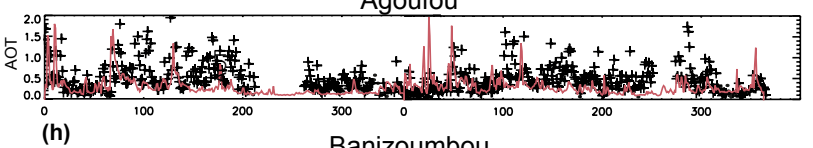

(h) Banizoumbou

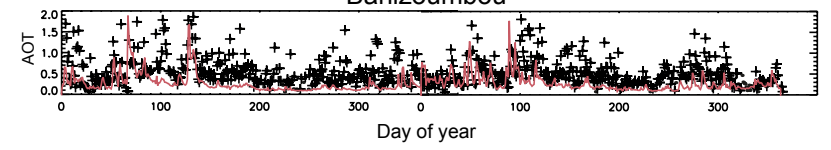

Fig. 5. Time series of daily modelled dust optical thickness (red line) and AOT measurements at $440 \mathrm{~nm}$ from AERONET at the stations Tamanrasset $\left(22.8^{\circ} \mathrm{N}, 5.5^{\circ} \mathrm{E}\right)$, Blida $\left(36.5^{\circ} \mathrm{N}, 2.9^{\circ} \mathrm{E}\right)$, Saada $\left(31.6^{\circ} \mathrm{N}, 8.2^{\circ} \mathrm{W}\right)$, Dakar $\left(14.4^{\circ} \mathrm{N}, 17.0^{\circ} \mathrm{W}\right)$, that are located in the vicinity of the Saharan desert, Banizoumbou $\left(13.5^{\circ} \mathrm{N}, 3.7^{\circ} \mathrm{E}\right)$ and Agoufou $\left(15.3^{\circ} \mathrm{N}, 1.5^{\circ} \mathrm{W}\right)$ in the Sahel, and the island locations Cape Verde $\left(16.7^{\circ} \mathrm{N}, 22.9^{\circ} \mathrm{W}\right)$ and Izana $\left(28.3^{\circ} \mathrm{N}, 16.5^{\circ} \mathrm{W}\right)$ (black plus signs) for 2007 and 2008. The black dots represent AOT measurements for Ångstrom parameters larger than 0.7 where dust AOT is not dominant.

spring and even more evident at Tamanrasset in the summer months (Fig. 5). There, the model does not reproduce a number of dust events in both years, and at this station the correlation coefficient between model and observations has a low value of only 0.14. At Agoufou and Banizoumbou, where the negative bias and root mean square errors are highest of all stations (Table 2), the model underestimates may be due to influences from other aerosols. The locations in the Sahel may be influenced by biomass burning and anthropogenic aerosols, that are not considered in the model. The stations Dakar, Capo Verde and Sal are additionally influenced by aerosol types other than dust from marine and 

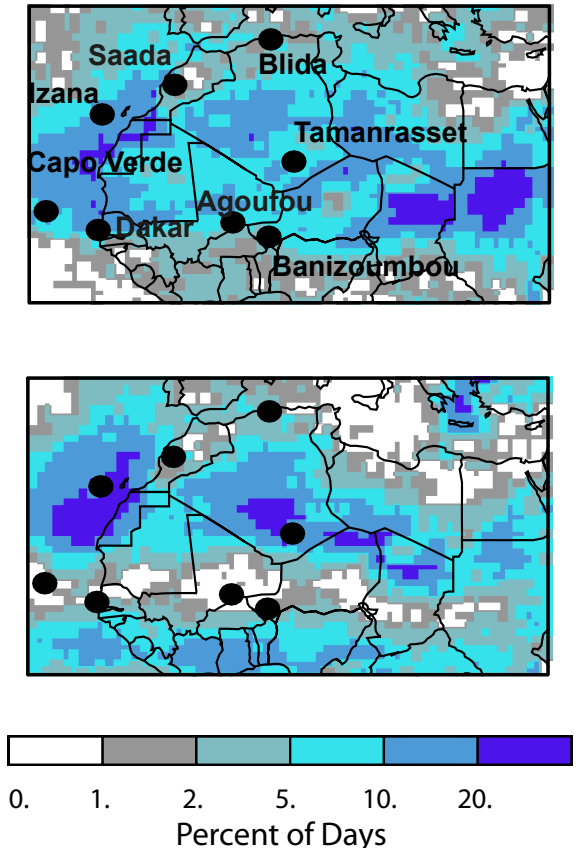

Fig. 6. Percent of days when low level jets occur in the COSMO model results averaged for 2007 and 2008 for the months April to June (top panel) and July to September (bottom panel). The locations of the AERONET stations used for model evaluation are indicated on the maps.

anthropogenic sources, which are not included in the model. Therefore the model that computes only dust optical thicknesses underestimates the measurements at these locations, leading to the negative bias. However, seasonal changes are reproduced by the model. Also, individual high dust events (e.g. Capo Verde in 2007) are simulated by the model. At the station Tamanrasset (located in Algeria in the vicinity of the Ahaggar mountains) the modelled dust AOT in the summer does not match several observed dust events and does not reach more than approximately $30 \%$ of the observed AOT magnitudes in both years. This strong underestimate is likely due to failures in the model to reproduce the meteorological conditions correctly that lead to dust emission upwind of this location at this time of the year. It could be either due to dust emitted by wet convective events, which the model does not reproduce, or due to insufficiently resolved topography resulting in incorrect wind fields in this mountainous area. It may also be possible that the emission scheme used in the model is unsuitable for this terrain and should be modified accordingly. Dedicated sensitivity studies of selected dust storm cases should be carried out to clarify the likely causes of this model shortcoming. It is notable that both regions influencing the AERONET stations - Agoufou in Northern Hemisphere spring and Tamanrassett in the summer months - are affected by the occurrence of LLJs (Fig. 6). Thus here it could be argued that the underestimate in modelled dust events and AOTs could be at least partly due to the underestimate in dust emission fluxes by the morning break-down of nocturnal LLJs.

\section{Conclusions}

Comparing the results of a two-year regional model simulation of Saharan dust distributions with the DSA record compiled from the MSG IR dust index highlighted some strengths and weaknesses of both the model and the observational dataset. The observations from the MSG IR dust index derived with a backtracking method point toward the foothills of mountains as notable source regions in addition to hot spots like the Bodélé depression (Schepanski et al., 2012). The data also highlight the important role of the development of nocturnal LLJs for the frequency of dust emission events for large parts of the Sahara. LLJs develop above the stable nocturnal boundary layer; after sunrise when the surface heats up, their momentum is mixed to the surface by turbulence. In the model this process is also reproduced, but LLJs lead less frequently (and later in the day) to dust emission compared to the observations. While it is possible that LLJs develop too weakly and their degradation is delayed in the model due to an inappropriate boundary layer parameterization, it is also possible that the spatial model resolution is still too coarse to resolve strong gradients in the topography. This would mean that a model grid cell with a horizontal grid size of $28 \mathrm{~km}$ is represented by a high roughness length that leads to suppression of dust emissions in these areas. In contrast, fluvial sediments at mountainsides or foothills of mountains are frequently observed to be active dust sources. The dust emission scheme used in the regional model will need to be adapted to represent such sources appropriately.

While the model may be deficient in reproducing dust emission events in mountainous regions, the satellite observations in turn may miss dust emissions that occur below an existing dust cloud. This may be the case for dust emissions related to the passage of cyclonic fronts in the northern Sahara in the late winter and spring months and moist convective systems in the Sahel and southern Sahara in summertime. Such missed dust emission events may be the cause of a bias toward the morning hours in the DSA derived from MSG observations. These issues need to be considered when conducting model-data comparisons of dust source activation events.

The model results agree with the AERONET optical thickness data in the magnitude of modeled AOT and for a large part of the day-to day variations, while discrepancies are also noted between model results and observations in the day to day changes of dust AOT. In the AERONET data no significant AOT increase is found from year 2007 to 2008. In contrast, compared to the DSA observations, the year-to-year changes are underpredicted in the model. This may be an indication that the frequency of dust emission events is not 
necessarily a good indicator for dust emission fluxes in the Sahara desert. In addition, the MSG infrared dust index data need to be interpreted carefully, since the magnitude of the IR signal depends on factors like the specific humidity and temperature profiles. Ideally the model should be modified such that it directly simulates the satellite observables to facilitate a quantitative comparison.

Acknowledgements. The authors thank the Deutscher Wetterdienst (DWD) for good cooperation and support. We thank NASA GES DISC for development and maintenance of Giovanni online system providing OMI AI data. We thank P. Goloub, D. Tanré, B. Holben, B. Mougenot and B. Duchemin, as well as E. Cuevas-Agullo for their efforts in establishing and maintaining the AERONET sites Agoufou, Banizoumbou, Blida, Capo Verde, Dakar, Izana, Saada and Tamanrasset. A part of this work has been funded by the the BMBF (Bundesministerium für Bildung und Forschung) as part of the SOPRAN project, which is a German national contribution to the International SOLAS project. KS and BH also acknowledge funding from European Research Council Grant No. 257543 "Desert Storms".

Edited by: Y.-S. Chung

\section{References}

Alpert, P. and Ziv, B.: The Sharav Cyclone: Observations and some theoretical considerations, J. Geophys. Res., 94, 18495-18514, doi:10.1029/JD094iD15p18495, 1989.

Berge, E.: Transboundary air pollution in Europe, in: MSC-W Status Report 1997, Part 1 and 2, EMEP/MSC-W Report 1/97, The Norwegian Meteorological Institute, Oslo, 1997.

Bou Karam, D., Flamant, C., Tulet, P., Chaboureau, J.-P., Dabas, A., and Todd, M. C.: Estimate of Sahelian dust emissions in the intertropical discontinuity region of the West African Monsoon, J. Geophys. Res., 114, D13106, doi:10.1029/2008JD011444, 2009.

Brindley, H., Knippertz, P., Ryder, C., and Ashpole, I..: A critical evaluation of the ability of the Spinning Enhanced Visible and Infrared Imager (SEVIRI) thermal infrared red-green-blue rendering to identify dust events: Theoretical analysis, J. Geophys. Res., 117, D07201, doi:10.1029/2011JD017326, 2012.

Chiapello, I., Moulin, C., and Prospero, J. M.: Understanding the long-term variability of African dust transport across the Atlantic as recorded in both Barbados surface concentrations and large-scale Total Ozone Mapping Spectrometer (TOMS) optical thickness, J. Geophys. Res., 110, D18S10, doi:10.1029/2004JD005132, 2005.

DeMott, P. J., Sassen, K., Poellot, M. R., Baumgardner, D., Rogers, D. C., Brooks, S. C., Prenni, A. J., and Kreidenweis, S. M.: African dust aerosols as atmospheric ice nuclei, Geophys. Res. Lett., 30, 1732, doi:10.1029/2003GL017410, 2003.

Dubovik, O., Holben, B. N., Eck, T. F., Smirnov, A., Kaufman, Y. J., King, M. D., Tanré, D., and Slutsker, I.: Climatology of absorption and optical properties of key aerosol types, J. Atmos. Sci., 59, 590-608, 2002.

Heinold, B., Helmert, J., Hellmuth, O., Wolke, R., Ansmann, A., Marticorena, B., Laurent, B., and Tegen, I.: Regional model- ing of Saharan dust events using LM-MUSCAT: Model description and case studies, J. Geophys. Res., 112, D11204, doi:10.1029/2006JD007443, 2007.

Heinold, B., Tegen, I., Esselborn, M., Kandler, K., Knippertz, P., Müller, D., Schladitz, A., Tesche, M., Weinzierl, B., Ansmann, A., Althausen, D., Laurent, B., Massling, A., Müller, T., Petzold, A., Schepanski, K., and Wiedensohler, A.: Regional Saharan dust modelling during the SAMUM 2006 campaign, Tellus B, 61, 307-324, 2009.

Heinold, B., Tegen, I., Schepanski, K., Tesche, M., Esselborn, M., Freudenthaler, V., Gross, S., Kandler, K., Knippertz, P., Müller, D., Schladitz, A., Toledano, C., Weinzierl, B., Ansmann, A., Althausen, D., Müller, T., Petzold, A., and Wiedensohler, A.: Regional modelling of Saharan dust and biomass-burning smoke, Tellus B, 63, 781-799, doi:10.1111/j.1600-0889.2011.00570.x, 2011.

Helmert, J., Heinold, B., Tegen, I., Hellmuth, O., and Wendisch, M.: On the direct and semi-direct effect of Saharan dust over Europe: A case study, J. Geophys. Res, 112, D13208, doi:10.1029/2006JD007444, 2007.

Holben B. N., Eck, T. F., Slutsker, I., Tanré, D., Buis, J. P., Setzer, A., Vermote, E., Reagan, J. A., Kaufman, Y., Nakajima, T., Lavenu, F., Jankowiak I., and Smirnov, A.: AERONET - A federated instrument network and data archive for aerosol characterization, Remote Sens. Environ., 66, 1-16, 1998.

Horvath, K., Fita, L., Romero, R. and Ivancan-Picek, B.: A numerical study of the first phase of a deep Mediterranean cyclone: Cyclogenesis in the lee of the Atlas Mountains, Meteor. Z., 15, 133-146, doi:10.1127/0941-2948/2006/0113, 2006.

Huneeus, N., Schulz, M., Balkanski, Y., Griesfeller, J., Prospero, J., Kinne, S., Bauer, S., Boucher, O., Chin, M., Dentener, F., Diehl, T., Easter, R., Fillmore, D., Ghan, S., Ginoux, P., Grini, A., Horowitz, L., Koch, D., Krol, M. C., Landing, W., Liu, X., Mahowald, N., Miller, R., Morcrette, J.-J., Myhre, G., Penner, J., Perlwitz, J., Stier, P., Takemura, T., and Zender, C. S.: Global dust model intercomparison in AeroCom phase I, Atmos. Chem. Phys., 11, 7781-7816, doi:10.5194/acp-11-7781-2011, 2011.

Jickells T.D., An Z. S, Andersen, K. K., Baker, A. R., Bergametti, G., Brooks, N., Cao, N. N., Boyd, P. W., Duce, R. A., Hunter, K. A., Kawahata, H., Kubilay, N., LaRoche, J., Liss, P. J., Mahowald, N. M., Prospero, J. M., Ridgwell, A. J., Tegen, I., and Torres, R.: Global iron connections between desert dust, ocean biogeochemistry and climate, Science, 308, 67-71, 2005.

Koch, J. and Renno, N. O.: The role of convective plumes and vortices on the global aerosol budget, Geophys. Res. Lett., 32, L18806, doi:10.1029/2005GL023420, 2005.

Knippertz, P. and Todd, M. C.: Mineral dust aerosols over the Sahara: Meteorological controls on emission and transport and implications for modeling, Rev. Geophys., 50, RG1007, doi:10.1029/2011RG000362, 2012.

Knippertz, P., Trentmann, J., and Seifert, A.: Highresolution simulations of convective cold pools over the northwestern Sahara, J. Geophys. Res., 114, D08110, doi:10.1029/2008JD011271, 2009.

Lacis, A. A. and Mishchenko, M. I.: Climate forcing, climate sensitivity and climate response: a radiative modeling perspective on atmospheric aerosols, in Aerosol forcing of climate, edited by: Charlson, R. J. and Heintzenberg, J., 11-42, John Wiley \& Sons, Berlin, 1995. 
Laurent, B., Marticorena, B., Bergametti, G., Léon, J. F., and Mahowald, N. M.: Modeling mineral dust emissions from the Sahara desert using new surface and soil developments, J. Geophys. Res., 113, D14218, doi:10.1029/2007JD009484, 2008.

Laurent, B., Tegen, I., Heinold, B., Schepanski, K., Weinzierl, B., and Esselborn M.: A model study of Saharan dust emissions and distributions during the SAMUM-1 campaign, J. Geophys. Res., 115, D21210, doi:10.1029/2009JD012995, 2010.

Mahowald, N. M., Muhs, D. R., Levis, S., Rasch, P. J., Yoshioka, M., Zender, C. S., and Luo, C.: Change in atmospheric mineral aerosols in response to climate: Last glacial period, preindustrial, modern, and doubled carbon dioxide climates, J. Geophys. Res., 111, D10202, doi:10.1029/2005JD006653, 2006.

Marticorena, B. and Bergametti, G.: Modeling the atmospheric dust cycle 1 . Design of a soil-derived dust production scheme, J. Geophys. Res., 100, 16415-16430, 1995.

Marsham, J. H., Knippertz, P., Dixon, N. S., Parker, D. J., and Lister, G. M. S: The importance of the representation of deep convection for modeled dust-generating winds over West Africa during summer, Geophys. Res. Lett., 38, L16803, doi:10.1029/2011GL048368, 2011.

Prospero, J. M. and Lamb, P. J.: African droughts and dust transport to the Caribbean: Climate change implications, Science, 302, 1024-1027, 2003.

Reinfried, F., Tegen, I., Heinold, B., Hellmuth, O., Schepanski, K., Cubasch, U., Hübener, H., and Knippertz, P.: Density currents in the Atlas Region leading to dust mobilization: A model sensitivity study, J. Geophys. Res., 114, D08127, doi:10.1029/2008JD010844, 2009.

Schepanski, K., Tegen, I., Laurent, B., Heinold, B., and Macke , A.: A new Saharan dust source activation frequency map derived from MSG-SEVIRI IR-channels, Geophys. Res. Lett., 34, 18803, doi:10.1029/2007GL030168, 2007.

Schepanski, K., Tegen, I., Todd, M. C., Heinold, B., Bönisch, G., Laurent, B., and Macke, A.: Meteorological processes forcing Saharan dust emission inferred from MSG-SEVIRI observations of sub-daily source activation and numerical models, J. Geophys. Res., 114, D10201, doi:10.1029/2008JD010325, 2009.

Schepanski, K., Tegen, I., and Macke, A.: Comparison of satellite based observations of Saharan dust source areas, Remote Sensing of Environment, 123, 90-97, doi:10.1016/j.rse.2012.03.019, 2012.

Seinfeld, J. H. and Pandis, S. N.: Atmosheric Chemistry and Physics, 1326 pp., John Wiley \& Sons, New York NY, 1998.
Sokolik, I. N., Winker, D. M., Bergametti, G., Gillette, D. A., Carmichael, G., Kaufman, Y. J., Gomes, L. Schuetz, L., and Penner, J. E.: Introduction to special section: Outstanding problems in quantifying the radiative impacts of mineral dust, J. Geophys Res., 106, 18015-18027, doi:10.1029/2000JD900498, 2001.

Solomon, S., Qin, D., Manning, M., Marquis, M., Averyt, K., Tignor, M. M. B., and Miller, H. L. (Eds.): Climate Change 2007: The Physical Science Basis, 989 pp., Cambridge University Press, UK, 2007.

Steppeler, J., Doms, G., Schättler, U., Bitzer, H. W., Gassmann, A., Damrath, U., and Gregoric, G.: Meso-gamma scale forecasts using the nonhydrostatic model LM, Meteorol. Atmos. Phys., 82, 75-96, 2003.

Tegen, I., Harrison, S. P., Kohfeld, K. E., and Prentice, I. C.: Impact of vegetation and preferential source areas on global dust aerosol: Results from a model study, J. Geophys. Res., 107, 4576, doi:10.1029/2001JD000963, 2002.

Todd, M. C., Bou Karam, D., Cavazos, C., Bouet, C., Heinold, B., Baldasano, J. M., Cautenet, G., Koren, I., Perez, C., Solmon, F., Tegen, I., Tulet, P., Washington, R., and Zakey, A.: Quantifying uncertainty in estimates of mineral dust flux: An intercomparison of model performance over the Bodélé Depression, northern Chad, J. Geophys. Res., 113, D24107, doi:10.1029/2008JD010476, 2008.

Torres, O., Tanskanen, A., Veihelmann, B., Ahn, C., Braak, R., Bhartia, P. K., Veefkind, P., and Levelt, P.: Aerosols and surface UV products form Ozone Monitoring Instrument: An overview. J. Geophys. Res., 112, D24S47, doi:10.1029/2007JD008809, 2007.

Washington, R. and Todd, M. C.: Atmospheric controls on mineral dust emission from the Bodele depression, Chad: The role of the low level jet, Geophys. Res. Lett., 32, L17701, doi:10.1029/2005GL023597, 2005.

Wolke, R., Hellmuth, O., Knoth, O., Schröder, W., Heinrich, B., and Renner, E.: The chemistry-transport modeling system LMMUSCAT: Description and CITYDELTA applications, in: Air Pollution Modeling and its Applicaton XVI, edited by: Borrego, C. and Incecik, S., Kluwer Academic/Plenum Publishers, 427439, 2004.

Zobler, L.: A world soil file for global climate modeling, Tech. Rep. NASA TM-87802, 32 pp., NASA, Washington, DC, 1996. 